Original Research Paper

\title{
Methodology to Analyze the Stability of Bench Marks Applied for Settling Measurements of Buildings Foundation
}

\author{
${ }^{1}$ Andréa de Seixas and ${ }^{2}$ José Roberto de Seixas \\ ${ }^{1}$ Department of Cartographic Engineering, Federal University of Pernambuco, Recife, Brazil \\ ${ }^{2}$ CIENTEC Engenharia e Consultoria LTDA, Recife, Brazil
}

\author{
Article history \\ Received: 08-01-2020 \\ Revised: 08-02-2020 \\ Accepted: 12-03-2020 \\ Corresponding Author: \\ Andréa de Seixas \\ Department of Cartographic \\ Engineering, Pos Graduate \\ Program in Geodetic Sciences \\ and Geoinformation \\ Technologies, Federal \\ University of Pernambuco, \\ Recife, Brazil \\ Email: aseixas@ufpe.br
}

\begin{abstract}
In this work, one type of vertical bench mark is presented for the realization of the Vertical Local Geodetic Network for the control and analysis of settling foundation elements. The revision of the previous norm NBR 6122/96 to the current norm NBR 6122/2010, contributed in Brazil to the obligation of the services of measurement of settlings in buildings with more than $60 \mathrm{~m}$ in height. This increased the demand for geodetic surveys to control the performance of building foundations. The vertical geodetic network determined by the high precision geometric leveling method materializes a vertical Reference System for the establishment of heights reference standards and investigation of vertical displacements of elements of the foundations of buildings, for example, of shoes and blocks. For economic reasons, in this work, the "static" Level References were embedded in pillars of building structure outside the domain of the work, with more than 50 years of post-construction and installed on Franki stakes. For this reason, it was necessary to create a Vertical Local Geodetic Network to transport height to the work, which allowed the study of the vertical behavior of three types of materialization of level references: embedded in building structure pillars; superficial and fixed on sidewalks; fixed at two meters deep and immediate to the building. So, this work aims to present the methodology to analyze the stability of bench marks used for the measurement of settlements in buildings under construction and post- construction.
\end{abstract}

Keywords: Bench Mark, Engineering Surveying, Settling Measurement, Vertical Local Geodetic Network, Standard of Height Reference

\section{Introduction}

The control and monitoring of the construction of buildings require the basic knowledge and experience of the technical methods of construction and the use of geodetic equipment.

Landslides, collapse, soil subsidence, as well as displacements of building structures are increasingly being detected in urban environments, where the development of buildings is notorious. As a result of this, in recent years, in addition to geotechnical and structural engineering, the growth and valorization of the use of geodetic methods in a Brazilian civil construction environment have been perceived. From the analysis and the field observations in geodesic structures, as a reference to the precise positioning of objects, we study the displacements, deformations and solutions most appropriate for the stability of the constructions (De Seixas et al., 2006; 2007; 2008; 2009; 2012; 2014; Silva and De Seixas, 2017a; 2019; De Seixas et al., 2019). Thus, an urban space densely occupied by the construction of buildings requires the definition and materialization of good quality planimetric and altimetric geodesic structures.

In works related to Engineering, reference points must be properly materialized and data must be observed with instruments classified according to standards as instruments of high and/or very high precision (Moeser et al., 2012). It is worth mentioning and emphasizing the existence of digital levels with completely automatic readings in bar charts, with bar code division (binary standard), through digital image processing and correlation calculations (Ingensand, 1990) and (Ingensand, 2002).

Geometric levels can be executed with a greater economy with the use of digital levels in a short period 
of time and free of reading and writing errors due to automatic measurement recording (Schwarz, 2002). The rotation of the digital levels can be controlled by motors, thus being able to automatically carry out with these instruments the measurement of predefined object-point heights during repeated measurements of the follow-up of the static constructions. Each point is materialized with an arrow. Under normal conditions of measurement and accuracy of $<0,1 \mathrm{~mm}$ (Schwarz, 2002). This type of geodetic technology certainly revolutionizes the whole measurement environment, which allows online monitoring of structures, such as in hazardous areas and provides innovative solutions adapted to each type of object.

With the geometric leveling method, the horizontal differences are determined by height differences between points close to one another (Kahmen, 2006).

The physical establishment of fixed points defining an altimetric, planimetric and/or planialtimetric reference, in the vicinity of the building structures and/or others, provide studies of vertical, horizontal and/or tridimensional movements of these structures. The definition of a reference system from a coordinate system and fixed points is of fundamental importance for the analysis of the measurement and monitoring of the work with respect to its displacement. The updating of standard NBR 6122/96 (ABNT, 1996a) to NBR $6122 / 2010$ (ABNT, 2010b), for example, contributed to the obligation of the services of measurement of settlings in buildings with more than $60 \mathrm{~m}$ in height. This increased the demand for surveys for the vertical control of buildings. To carry out this control, it is necessary to monitor the immediate vicinity of the pillars of the building. There is an appropriate Level Reference (RN) of good quality.

In De Seixas et al. (2012) the Verification and Vertical Control of Bench Mark (BM) is discussed. According to the authors, the proper determination of altimetric data for the transport of height is interconnected by the definition of geodesic structures, that is, a set of a field of reference points called the geodetic network.

A vertical reference system in a building construction site is usually fixed through an altimetric reference surface defined by a fictitious horizontal plane and its distance to a materialized altimetric fixed point and called Level Reference (RN) or Bench Mark (BM). A metal rod is used for the implantation of the BM, protected by an external tube and installed in a drilling hole at the percussion. Usually they are set in deep layers, through injection of cement cream, where the "not dislocated" is located. The BM must be installed so as not to suffer influence from the work itself or other causes that may compromise its stability. In this work, for economic reasons, the "static" Level References were embedded in pillars of building structure outside the domain of the work, with more than 50 years of postconstruction and installed on Frank stakes.

When it is necessary to know an absolute altitude value, it is linked to the country's official vertical network in the case of Brazil, which is linked to the High Accuracy Altimetry Network (HAAN) of the Brazilian Institute of Geography and Statistics (IBGE). de Freitas and Blitzkow (1999), Blitzkow et al. (2004) and Moeser et al. (2012) are defined and discussed the different types of altitudes (heights) and how they can be correlated with each other, as well as the discussion of the different instrumentalizations needed to define them.

One vertical local geodesic network is presented in this work in two different cases, both involving bench mark application. In the first case, the accomplishment of the height reference system is presented and in the second case, the study and analysis of basements of foundation elements are presented.

In addition, this work aims to present a methodology to analyze the stability of the standard Level References used for the measurement of settlements in buildings under construction.

This work has been running since May 2015 and is associated with a research project under development entitled "Control and Monitoring of Settlements Building under Construction of the Integrated Laboratory for Technology in Oil, Gas and Biofuels LITPEG/CTG/UFPE" involving the study of materialization and behavior of vertical local geodetic network, control and monitoring of settlements, study of the behavior of building foundations, verification of digital level performance, studies of verticalization of buildings, horizontalization of platforms, graphic visualization, optimization of measurement procedures and geodetic instrumentation, favoring studies and research in the area of Applied Geodesy and Geotechnics (de Seixas and de Seixas, 2015; 2018).

The shortage of practical material (from real case studies) and theoretical reference to the methodology for the control and monitoring of buildings by utilizing optical measurement procedures, located in urbanized sites, encouraged the development of this work.

\section{Methodology for the Analysis of the Stability of the Bench Marks}

The UFPE campus recife has a set of important geospatial information to perform the practical activities of teaching, research and extension of the Cartographic Engineering and Civil Engineering courses, among others. These geodesic data also support the physical 
infrastructure of the works and building management of several Campus Centers. Because of the courses of the Technology and Geosciences Center (TGC), especially the Cartographic Engineering Course founded in 1971, geodesic landmarks of national and international character were established and interconnected to the Brazilian Geodetic System. Thus, geodesic structures defined in the SIRGAS2000 Brazilian Geodetic System are protected by law and homologated by the Brazilian Institute of Geography and Statistics (IBGE). Types of geodesic structures include GNSS station of the RBMC, geodesic landmarks of the first order, Level References and triangulation vertices. With the development of classes and research linked to the Cartographic Engineering Course and the Postgraduate Course in Geodetic Sciences and Geoinformation Technologies, it was possible to expand the geodetic data infrastructure of the Campus. Thus, the work and research, concentrated in and around the campus, is aided the presence of several geodesic landmarks materialized in various making the Metropolitan Region of Recife (RMR) a privileged area.

The Vertical Local Geodetic Network of the UFPE Campus Recife is composed of 28 Level References implemented in 2015. In addition to these level references, the level references of the High Accuracy Altimetric Network (HAAN) of the IBGE are implanted within and around Campus. From this set of level references, six are part of the vertical network for settling measurements of buildings foundation presented below.

\section{Definition of the Experimental Area}

In 2015, in the Technology and Geosciences Center (TGC), two level reference sets were placed in two pillars located on the ground floor of the façade of the school building. The pieces were made of stainless steel with spherical supports (Fig. 1).

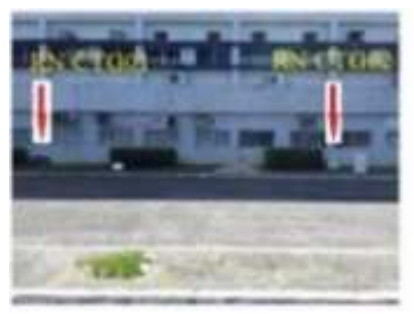

A

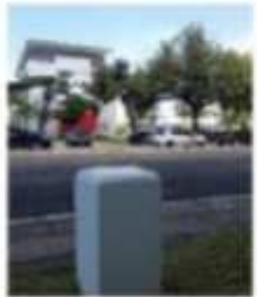

$\mathrm{D}$

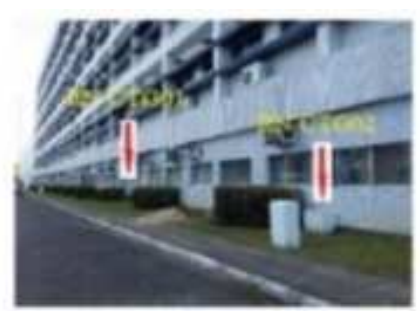

B
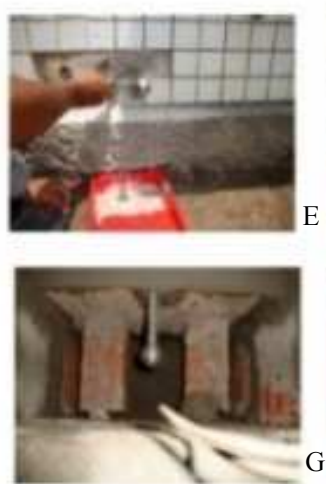
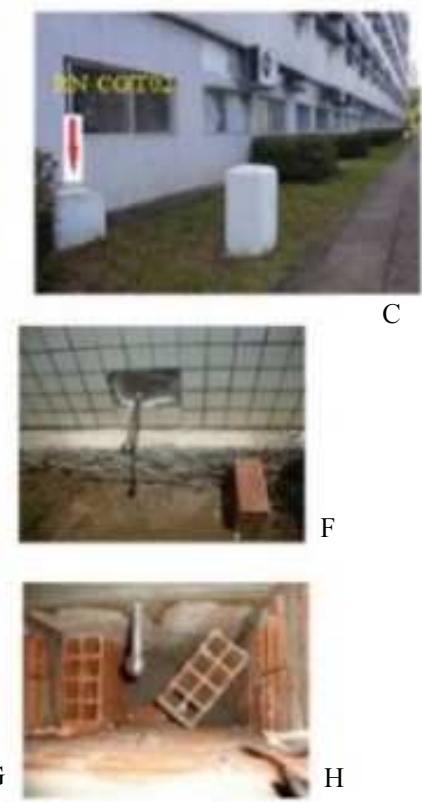

Fig. 1:TGC Level References: A. TGC school building and front facade; B. Front view to the right of the RN CTG01 and RN CTG02; C. Front view to the left of RN CTG02; D. Building LITPEG/UFPE built and view of RN CTG 02 to the building; E. a H. Materialization of the RN CTG01 and RN CTG02

Also implemented in 2015, nearby the LITPEG buildings, were two level references sets RN LITPEG01 and RN LITPEG02 (Fig. 2). These are used in the procedure of the control and monitoring of settlements during the period of measurement. The two level references were manufactured following the recommendations described in (De Seixas and Seixas, 2015). Since the Level References RN CTG01 and RN CTG02 used as heights standards and presented in this work are outside the work environment, as previously described. The usefulness of these level references considers the time of measurement and the function of transferring the vertical reference at the instant of the measurement procedure for the measurement of the settling of the pins fixed in the pillars in the buildings under monitoring. The behavior of these level references will also be approached in this work. 

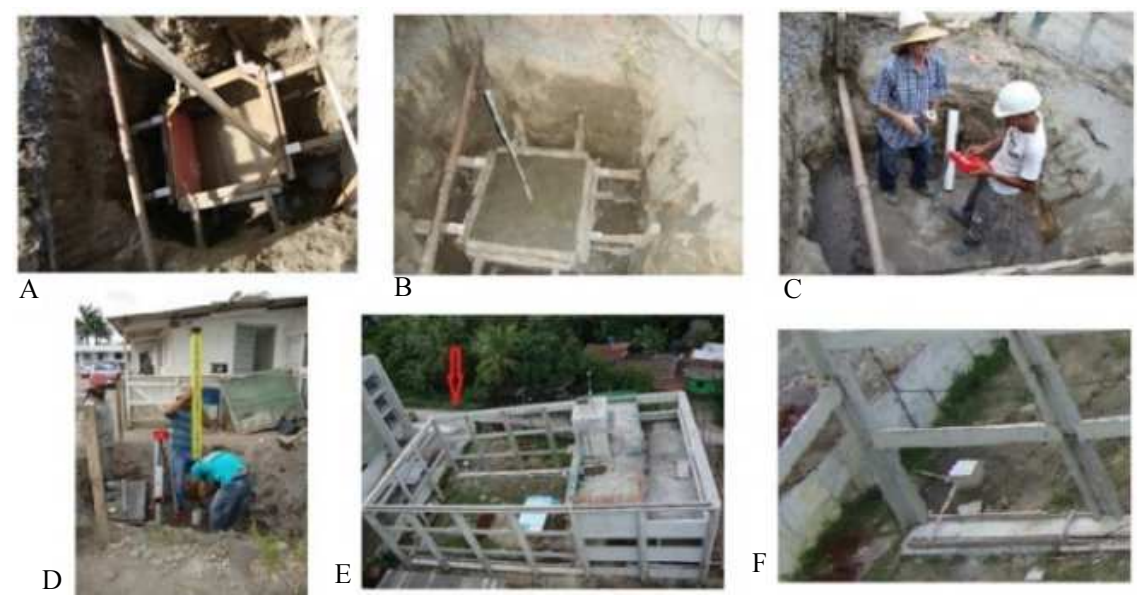

Fig. 2: Level References of the LITPEG work. A. Construction of RN LITPEG01; B. Concrete of the base and fixation of the metal rod; C. Fixation of BM; D. RN LITPEG01 and support of the rod sight; E. and F. Location of RN LITPEG02

Between the Technology and Geosciences Center and LITPEG buildings, the Verification Base was built and the adjustment of levels were composed from four level references RNA, RNB, RNC and RND (Fig. 3).

To facilitate digital level checks and/or adjustments, four pins of semi-spherical surfaces were implanted in the sidewalk of the central parking lot in front of the TGC school building, according to ISO 17123 - part 2 (ISO, 2001). The digital level was continuously checked and adjusted, when necessary, regarding the collimation error. To verify its accuracy and performance, three verification campaigns were carried out (one in November 2015, one in January 2017 and one in May 2018), following the simple method and the complete method described in ISO 17123-part 2 (ISO, 2001). The results indicated that the accuracy of the equipment is classified within the specification of the level, i.e., $0,3 \mathrm{~mm} / \mathrm{km}$ double level. The results regarding the tests and the analysis of the level precision can be seen in (Silva, 2017), (Santos et al., 2019), (Silva and De Seixas, 2017b) and (Silva et al., 2018).
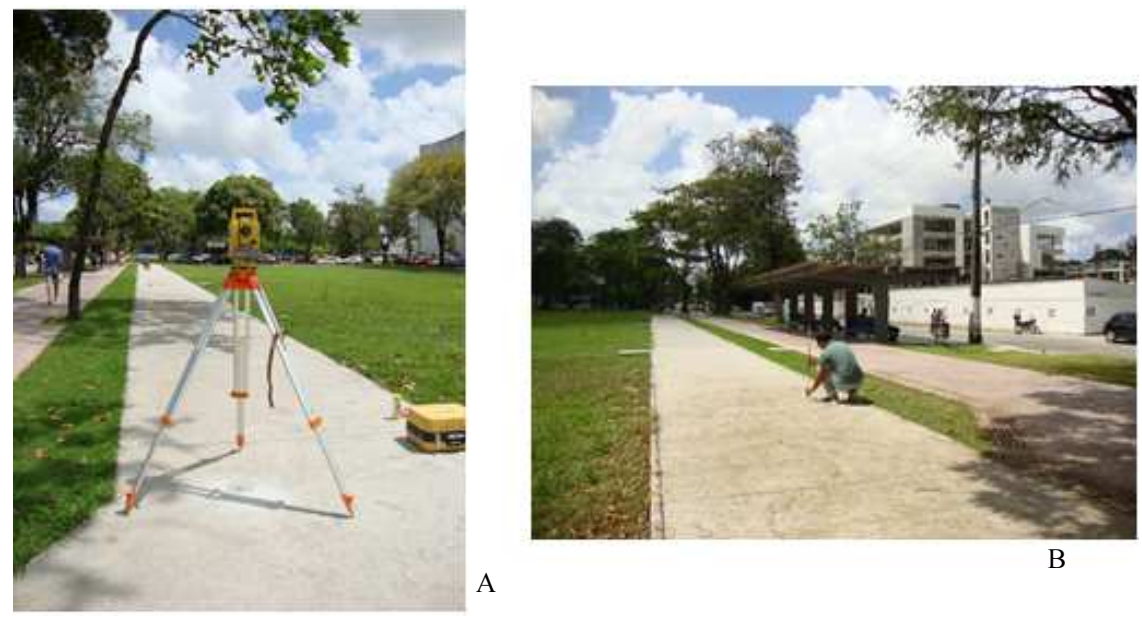

Fig. 3: Verification base and level adjustment: RNA and RND level references. A. RNA; B. RND

The level references were observed from the leveling and counter-leveling (RN CTG01 - RN CTG02 - RN CTG01). In Fig. 4 the leveling line is $l 1$ and the counterleveling line is $l 6$. These leveling lines were measured over 19 measurement campaigns for 1159 days. These campaigns involved the analysis of these standard level references and the height transport to the level references located near the construction site, involving the Vertical Local Geodetic Network (Fig. 4) for the settlement measurements and survey of the settling pins implanted in the pillars of the buildings that are being monitored (De Seixas and de Seixas, 2019). 


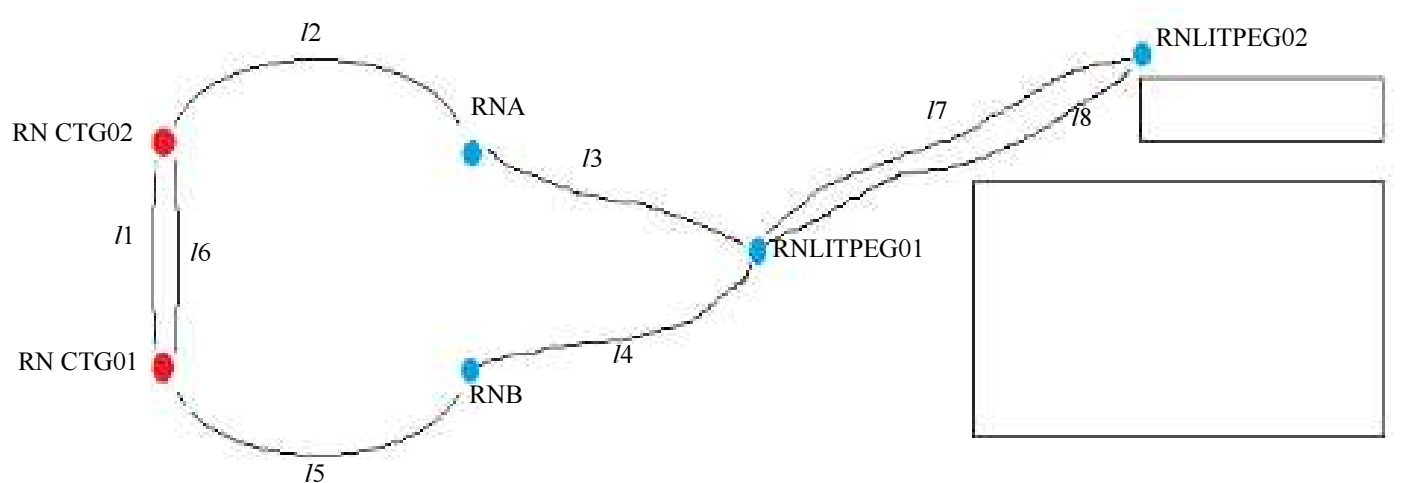

Fig. 4: Outline of the vertical local geodetic network leveling lines for the settlement measurements

Figure 4 illustrates the Vertical Local Geodetic Network involving the two bench marks (RN CTG01 and RN CTG02), the two superficial, fixed on sidewalks, level references (RNA and RNB) of the level verification base and the two level references fixed at two meters deep and immediate to the work construction (RN LITPEG01 and RN LITPEG02). Contemplating eight lines of leveling.

\section{Definition of the Vertical Reference System}

The vertical reference system, in the work of civil construction of buildings, is fixed through one reference surface defined by one fictitious horizontal plane and its distance from a materialized vertical fixed point, called the level reference.

In this work, the reference surface is represented by a horizontal plane tangent to the Bench Mark RN CTG01 called vertical reference "zero" of the work. All other heights of the field points are related to this fictitious horizontal reference plane.

Measurements of the Vertical Local Geodetic Network Densified in the Campus Recife of UFPE for the Measurement of Settlements

In this work, the evaluation of the quality control of geometric leveling obeyed the following aspects (De Seixas et al., 2014):

- From the verification of the digital level used

- On-site due to observations made in the field and their respective deviations

- From the calculation of the closing error in the geometric leveling circuits

- From the use of targets from equal distances

- Applying the correction of the effect of the terrestrial curvature
Prior to all measurement campaigns, the digital level is checked and/or adjusted to determine the collimation error. In addition, the level was verified according to ISO 17123-part 2 (ISO, 2001) to analyze its performance and accuracy. In order to carry out these verification procedures, a verification and adjustment base of digital levels (Fig. 3) was implemented within the Campus of UFPE, as previously described.

Geometric leveling for height transport was carried out using a Leica DNA-03 digital level $( \pm 0.3 \mathrm{~mm} / \mathrm{km}$ double precision) and a corresponding $2 \mathrm{~m}$ steer sight and logistic support. For the quality of the observations, the level was programmed to perform two sets of four readings each, accepting the average of the observations of the series, whose amplitude was less than or equal to $0,06 \mathrm{~mm}$. Remembering that the "EC" correction command of the readings with respect to the effects of the terrestrial curvature was activated.

Determination of Adjusted Benchmark Height: $R N$ CTG02 and Analysis of the Quality of the Benchmarks RNCTG01 and RNCTG02

In this item, the determination of the adjusted heights of the Benchmark RN CTG02 in the survey case performed and contemplating the vertical local geodetic network is considered.

Table 1 shows the results of the measurements carried out, i.e., the date of observation, the leveling and leveling closure error, the perimeter, the tolerance and the adjusted height of the RN CTG02, RN CTG01 was used as a vertical reference equal to $0 \mathrm{~m}$. The accuracy of the leveling and the tolerance were calculated from Equation 1 and Equation 2, the latter described in (Kahmen, 2006) and (Silva and Segantine, 2015):

$s=\sqrt{\frac{(E f)^{2}}{2 d}}$ 


$$
T=1 m m * \sqrt{d}
$$

Where:

$E f=$ The closing error $(\mathrm{mm})$

$D=$ The perimeter $(\mathrm{km})$

$T=$ The Tolerance $(\mathrm{mm})$

$s=$ The accuracy leveling $(\mathrm{mm} / \mathrm{km})$

According to the results presented in Table 1, it can be observed that the adjusted RN CTG02 range varies from $34,56 \mathrm{~mm}$ (L02) to $34,75 \mathrm{~mm}$ (L13), that is, an amplitude of $0,19 \mathrm{~mm}$. The smallest closing error varies in magnitude from $0,00 \mathrm{~mm}$ (LRP) to 0,17 $\mathrm{mm}$ (L09). For Reading (L05), the perimeter formed between the leveling lines $l 1$ to $l 5$ was considered (Fig. 4). Because of the rain during the measurement, it was not possible to measure line 16 . The accuracy of the leveling ranges from $\pm 0,00 \mathrm{~mm} / \mathrm{km}$ to $\pm 0,000030$ $\mathrm{mm} / \mathrm{km}$, i.e. $0,00 \mathrm{~mm} / \mathrm{km}$. The leveling circuit between RN CTG01 and RN CTG02 is very small. The tolerance of the leveling was considered, a $1 \mathrm{~mm} / \mathrm{km}$ double level, according to Torge (2001). It is observed in Table 1 that the closing error is considerably lower than the tolerance established, since the digital level used is of very high precision, according to ISO 17123-part 2 ISO (2001).
Table 1: Leveling and counter-leveling: RNCTG01-RNCTG02 - RNCTG01

\begin{tabular}{lllll}
\hline & & & & Ajusted height \\
Campaign/date & $E f(\mathrm{~mm})$ & $d(\mathrm{~m})$ & $T(\mathrm{~mm})$ & CTG02 $(\mathrm{mm})$ \\
\hline L01/24/09/2015 & $-0,04$ & 64,140 & $\pm 0,25$ & 34,60 \\
L02/21/10/2015 & $-0,03$ & 63,850 & $\pm 0,25$ & 34,56 \\
L03/26/11/2015 & 0,02 & 63,800 & $\pm 0,25$ & 34,58 \\
L04/02/02/2016 & 0,01 & 63,725 & $\pm 0,25$ & 34,56 \\
L05/03/03/2016 & 0,03 & 241,130 & $\pm 0,49$ & 34,58 \\
L06/14/04/2016 & $-0,01$ & 62,625 & $\pm 0,25$ & 34,62 \\
L07/18/05/2016 & $-0,08$ & 63,610 & $\pm 0,25$ & 34,62 \\
L08/30/06/2016 & 0,03 & 60,995 & $\pm 0,25$ & 34,60 \\
L09/26/08/2016 & 0,17 & 63,780 & $\pm 0,25$ & 34,58 \\
L10/18/11/2016 & $-0,02$ & 61,770 & $\pm 0,25$ & 34,63 \\
L11/02/02/2017 & $-0,06$ & 62,350 & $\pm 0,25$ & 34,64 \\
L12/18/05/2017 & $-0,09$ & 62,450 & $\pm 0,25$ & 34,62 \\
L13/02/08/2017 & $-0,02$ & 63,270 & $\pm 0,25$ & 34,75 \\
L14/01/11/2017 & 0,09 & 63,975 & $\pm 0,25$ & 34,62 \\
L15/02/02/2018 & $-0,04$ & 64,260 & $\pm 0,25$ & 34,71 \\
L16/25/04/2018 & $-0,03$ & 70,475 & $\pm 0,26$ & 34,59 \\
LRPa/20/06/2018 & 0,00 & 61,890 & $\pm 0,25$ & 34,59 \\
L17/15/08/2018 & 0,03 & 63,020 & $\pm 0,25$ & 34,64 \\
L18/26/11/2018 & 0,02 & 62,385 & $\pm 0,25$ & 34,60 \\
\hline L LRP - Rea
\end{tabular}

a. LRP - Readout of Pin Resetting-Campaign carried out for the readjustment of "male" pin to support the sight and fixation of external coating in Aluminum Composite Material (ACM)

Figure 5 represents the "Height $\mathrm{x}$ Time" graphic of the Level Reference RN CTG02 during the 19 measurement campaigns performed.

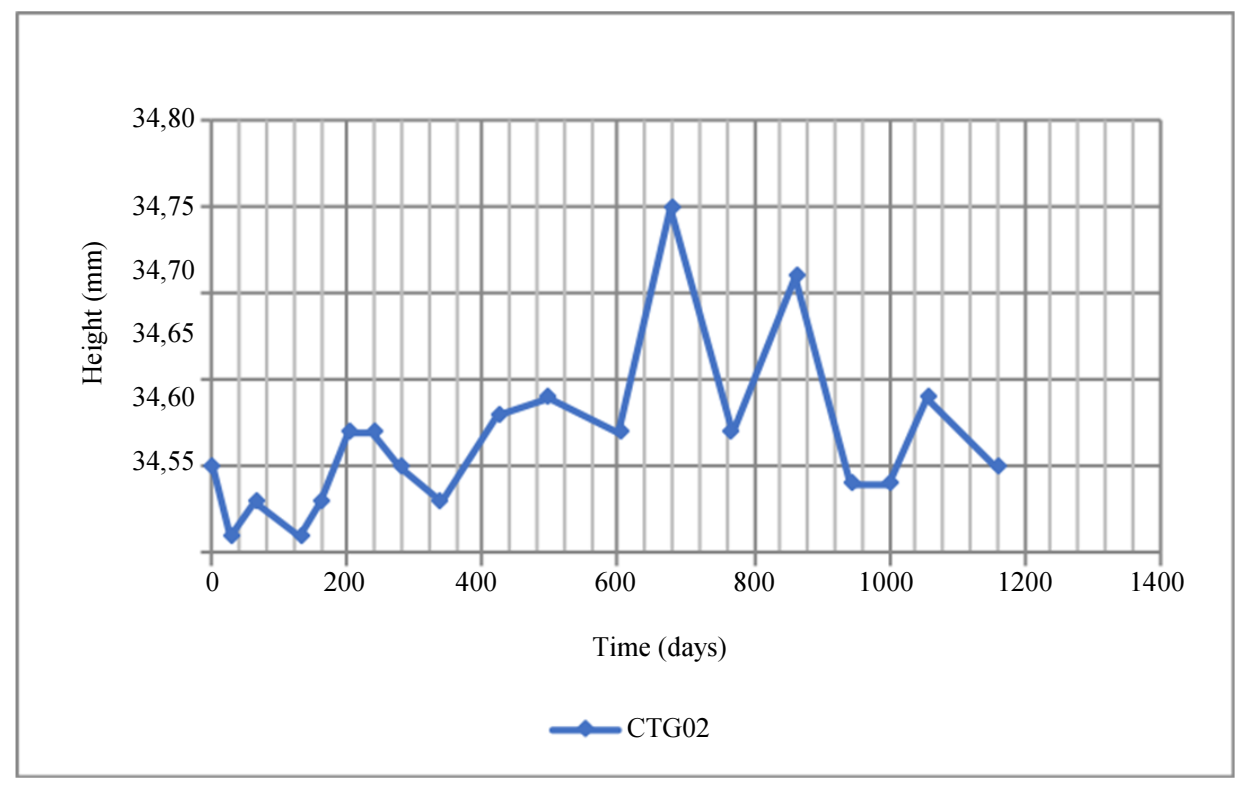

Fig. 5: "Height $\times$ Time" Graphic - RN CTG02

Fig. 6 represents the "Height $\mathrm{x}$ Time" graphic of the Level Reference RN CTG01 and RN
CTG02 during the 19 measurement campaigns performed. 


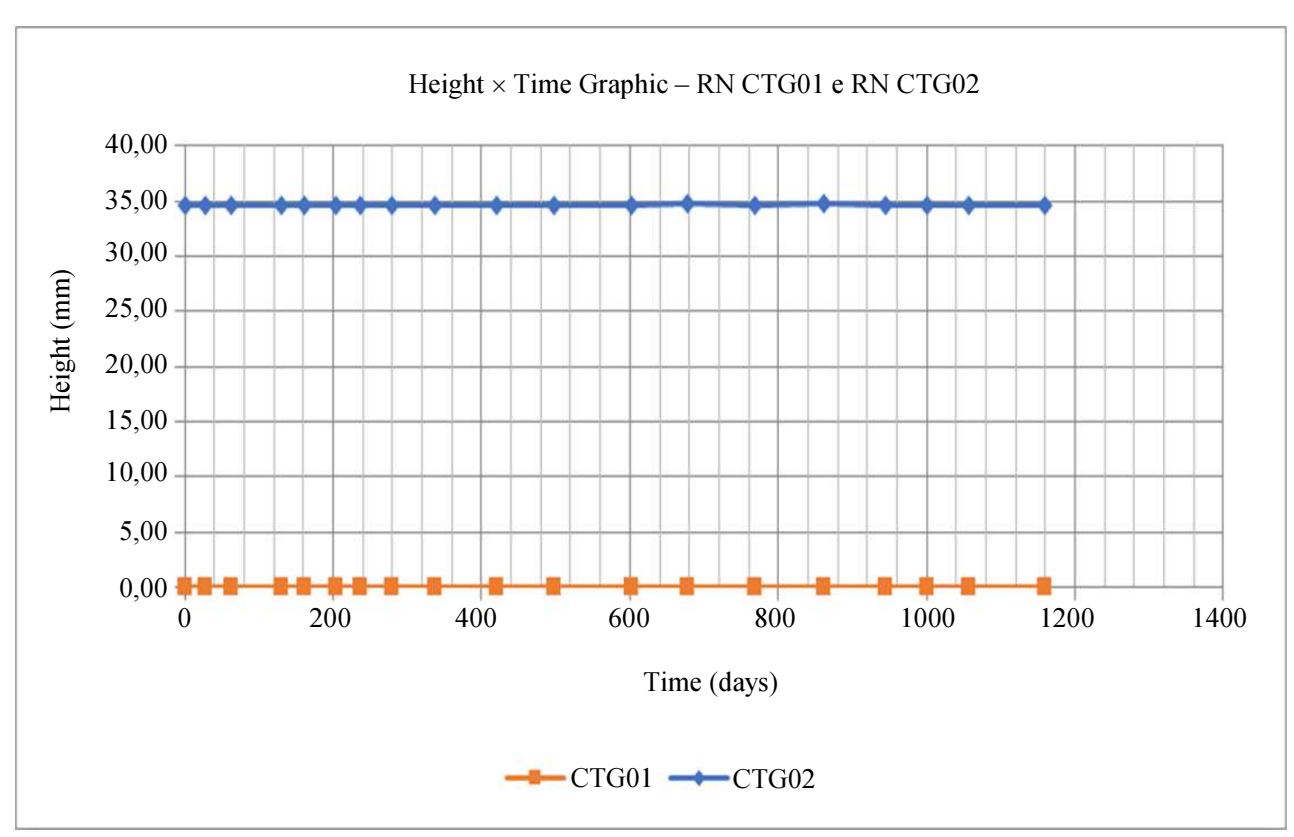

Fig. 6: "Height $\times$ Time" Graphic - RN CTG01 e RN CTG02

Once the adjusted heights of RN CTG02 were based on RN CTG01, it was possible to analyze the quality of both RN CTG01 and RN CTG02 Level References based on the analysis of means with the same variance, ANOVA and Linear Regression analysis. For further details see Wolf and Ghilani (1996), Gemael (1994), Niemeier (2002) and Moeser et al. (2012).

The t-student test was used for the analysis of means with the same variance. This work used the statistical module from the AstGeoTop software (Garnés, 2019). The mean values were calculated from the values of the adjusted heights of the RN CTG02 (Table 1).

For the statistical analysis, the heights, determined in the RN CTG02 calculated from the RN CTG01 and grouped by year were considered. By separating the measurements performed on 4 samples (sample 1: 3 Measurements in 2015, sample 2: 7 measurements in 2016, sample 3: 4 measurements in 2017 and sample 4: 5 measurements in 2018) according to Table 1 and with a significance level of $5 \%$, it was possible to statistically analyze the stability of the level references, according to the results presented in Table 2.

Table 2: Summary of the analysis of means with the same variance by $t$-student test

\begin{tabular}{llll}
\hline Groups & Estatistic t & t-critical & Conclusion \\
\hline Sample1 $\times$ Sample2 & 1,0890 & 2,306 & Not differ \\
Sample1 $\times$ Sample3 & 2,0315 & 2,571 & Not differ \\
Sample1 $\times$ Sample4 & 1,4501 & 2,447 & Not differ \\
Sample2 $\times$ Sample3 & 2,2467 & 2,262 & Not differ \\
Sample2 $\times$ Sample4 & 1,2257 & 2,228 & Not differ \\
Sample3 $\times$ Sample4 & 0,8339 & 2,365 & Not differ \\
\hline
\end{tabular}

Fonte: AstGeoTop (2019)
Therefore, performed among the samples presented in Table 2, with a Bi-flow rate of $\mathrm{t} \leq \mathrm{t}$-critical, the null hypothesis ( $\mathrm{H} 0$ : The same population means) from the Hypothesis test, can conclude that the sample means are equal to the significance level of $5 \%$.

To confirm the result obtained with the analysis of variances, the ANOVA analysis (single factor) was also applied. Tables 3 and 4 present the results of the analysis.

Table 3: Summary

\begin{tabular}{lllll}
\hline Group & Num. & Sum & Average & Variance \\
\hline Sample1 & 3 & 103,74 & 34,58 & 0,0004 \\
Sample2 & 7 & 242,19 & 34,60 & 0,0007 \\
Sample3 & 4 & 138,63 & 34,66 & 0,0039 \\
Sample4 & 5 & 173,13 & 34,63 & 0,0026 \\
\hline
\end{tabular}

Fonte: AstGeoTop (2019).

Table 4: ANOVA

\begin{tabular}{llrlll}
\hline Source of variation & S.Q. & GL & Q.M. & Estat-F & F-critical \\
\hline Between groups & 0,013 & 3 & 0,004 & 2,473 & 3,288 \\
Within the groups & 0,027 & 15 & 0,002 & & \\
Total & 0,040 & 18 & & & \\
\hline
\end{tabular}

Fonte: AstGeoTop (2019)

According to the results presented in Tables 3 and 4, it can be concluded that there are no differences between the groups at a significance level of $5 \%$. Table 5 shows the analysis of the differences by the Scheffé method, confirming that there are no significant differences between the samples. Specifically, between the heights of the RN CTG02 calculated at the different observation periods presented in Table 1 . 
Table 5: Analysis of differences by the Scheffé method. Unit in hundredth of $\mathrm{mm}$

\begin{tabular}{llll}
\hline Groups & Dalfa & $\mid$ Med_i-med_j & Conclusion \\
\hline Sample1 $\times$ Sample2 & 0,092 & 0,019 & Not differ \\
Sample1 $\times$ Sample3 & 0,102 & 0,078 & Not differ \\
Sample1 $\times$ Sample4 & 0,097 & 0,046 & Not differ \\
Sample2 $\times$ Sample3 & 0,084 & 0,059 & Not differ \\
Sample2 $\times$ Sample4 & 0,078 & 0,027 & Not differ \\
Sample3 $\times$ Sample4 & 0,090 & 0,032 & Not differ \\
\hline Fon
\end{tabular}

Fonte: AstGeoTop (2019)

After verifying the stability between the RN CTG01 and RN CTG02 benchmarks (level references), a linear regression was applied to the height coordinates from RN CTG02. According to Wolf and Ghilani (1996), the decision on whether to use a straight line or other curve is made after plotting the data and studying their form, or by checking the size of the residuals after the leastsquares solution with the first selected line or curve.

The full stability of a point is represented graphically by a horizontal line. In this sense, it is expected that the behavior between these two level references will also be confirmed using Linear Regression.

By applying a linear regression in the set of the heights coordinates of the RN CTG02 described in Table 6 as a function of the accumulated days of the measurement intervals (L1 to L18) performed and described in Table 1, the adjusted slope values are obtained (m) and its respective intersection (b) in the $Y$-axis. In this work, the software Adjust 1995-2004 (version 3.0) was used to calculate the linear regression using the Least Squares
Method (Fit of points: General LSQ Line), whose residual results are described in Table 6.

Table 6: Days accumulated between measurements - X, Heights RN CTG02 - Y and their residues - V

\begin{tabular}{lcll}
\hline Station & $X$ (days accumulated $)$ & $Y(\mathrm{~mm})$ & $\mathrm{V}(\mathrm{mm})$ \\
\hline L1 & 0 & 34,60 & $-0,01$ \\
L2 & 27 & 34,56 & 0,03 \\
L3 & 63 & 34,58 & 0,01 \\
L4 & 131 & 34,56 & 0,04 \\
L5 & 161 & 34,58 & 0,02 \\
L6 & 203 & 34,62 & $-0,02$ \\
L7 & 237 & 34,62 & $-0,02$ \\
L8 & 280 & 34,60 & 0,00 \\
L9 & 337 & 34,58 & 0,03 \\
L10 & 421 & 34,63 & $-0,02$ \\
L11 & 497 & 34,64 & $-0,02$ \\
L12 & 602 & 34,62 & 0,00 \\
L13 & 678 & 34,75 & $-0,13$ \\
L14 & 769 & 34,62 & 0,01 \\
L15 & 862 & 34,71 & $-0,08$ \\
L16 & 944 & 34,59 & 0,05 \\
LRP & 1000 & 34,59 & 0,05 \\
L17 & 1056 & 34,64 & 0,00 \\
L18 & 1159 & 34,60 & 0,05 \\
\hline Fon & & &
\end{tabular}

Fonte: Adjust (1995-2004).

The values of the slope of the line $(\mathrm{m})$ and $y$-intercept (b) obtained after the adjustment were 0,00004889 and 34,59 , respectively.

The linear regression calculation was controlled using the Excel software data analysis tool. Figure 7 and 8 illustrate the residues and the adjusted line.

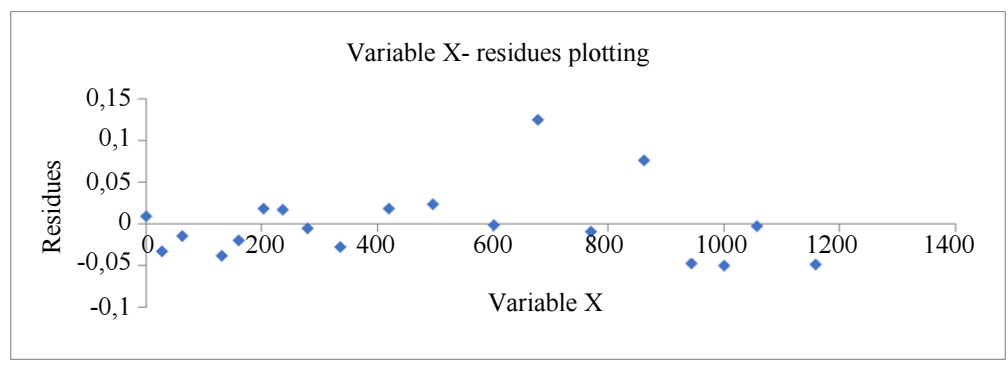

Fig. 7: Residues graphic

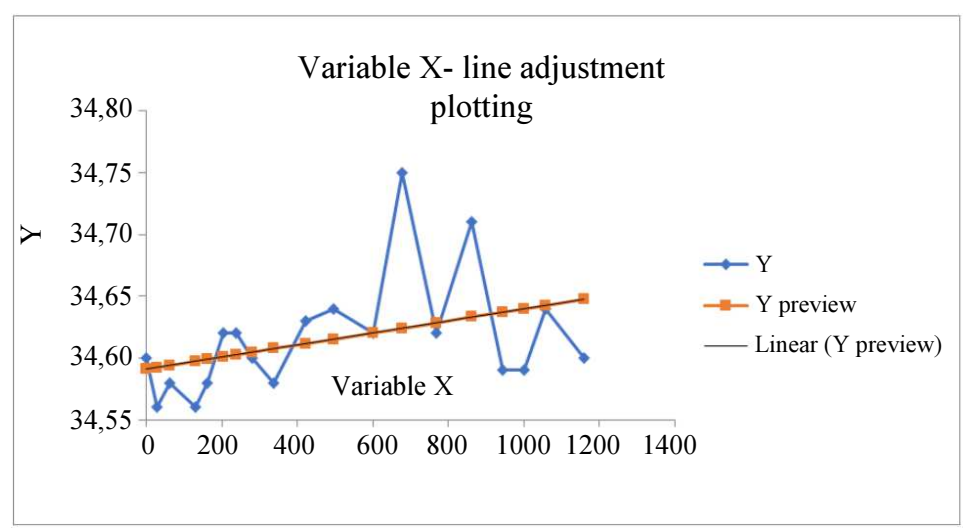

Fig. 8: Adjusted line chart-linear regression 
Determination and Analysis of Adjusted Heights: RNA, RNB, RN LITPEG01 and RN LITPEG02

In this work, the analysis of the stability of the heights determined for the level references RNA, RNB, RN LITPEG01 and RN LITPEG02 are considered. Theses level references are part of the Vertical Local Geodetic Network densified from the RN CTG01 and RN CTG02 for the analysis of settlings measurements of pins fixed on pillars of the LITPEG buildings under construction until the eighteenth campaign held on 11/26/2018. Fig. 4 illustrates the leveling lines observed during the campaigns carried out, whose measurement times are described in Table 1 and Table 6.

As shown in Fig. 4, a Vertical Local Geodetic Network was established for the measurements of control and monitoring of foundations settlements. The measurements of the network were made from the two Bench marks RN CTG01 and RN CTG02 towards the buildings and the level references implanted in the work (RN LITPEG01 and RN LITPEG02), passing through the level references of the base of verification and adjustment of levels, RNA and/or RNB, thus raising, in all the campaigns carried out 8 lines of leveling. This allowed the quality of the measurements made from the calculation of the closing error to be evaluated, as well as the accuracy and tolerance of the leveling. After analyzing the observed data, the calculations of the heights of the respective level references were performed, determining the heights of the respective level references, used in each measurement campaign. This procedure made it possible to evaluate the stability of the level references located near the work and to verify the behavior and vertical variability because they are superficial level references suffering vertical displacements.

Table 7 presents the minimum and maximum heights and respective range of the series of heights observed during the nineteen (19) campaigns carried out.

Table 7: Minimum and maximum heights of level references: RNA, RNB, RN LITPEG01 and RN LITPEG02 and respective amplitudes of the height series observed for each level reference

\begin{tabular}{llll}
\hline & $\begin{array}{l}\text { Minimum } \\
\text { height }(\mathrm{mm})\end{array}$ & $\begin{array}{l}\text { Maximum } \\
\text { height }(\mathrm{mm})\end{array}$ & Amplitude $(\mathrm{mm})$ \\
\hline RN & $-631,82$ & $-637,98$ & 6,16 \\
RNA & $-645,32$ & $-654,01$ & 8,69 \\
RNLITPEG01 & $-1145,64$ & $-1164,65$ & 19,01 \\
RNLITPEG02 & $-231,53$ & $-243,73$ & 12,20 \\
\hline
\end{tabular}

Figure 9 to 12 represent the graphics "Heights $\mathrm{x}$ Time" of the RNA, RNB, RN LITPEG01 and RN LITPEG02. Observe in the graphics the vertical variability and the downward direction of the heights in the graphics. RNA and RN LITPEG01 were observed during all periods described in Table 1, the RNB was not observed during the LRP and L17 measurements, totaling 17 observational periods and RNLITPEG02 was observed from the reading L7 onwards, totaling to measure L18 thirteen epochs of observation.

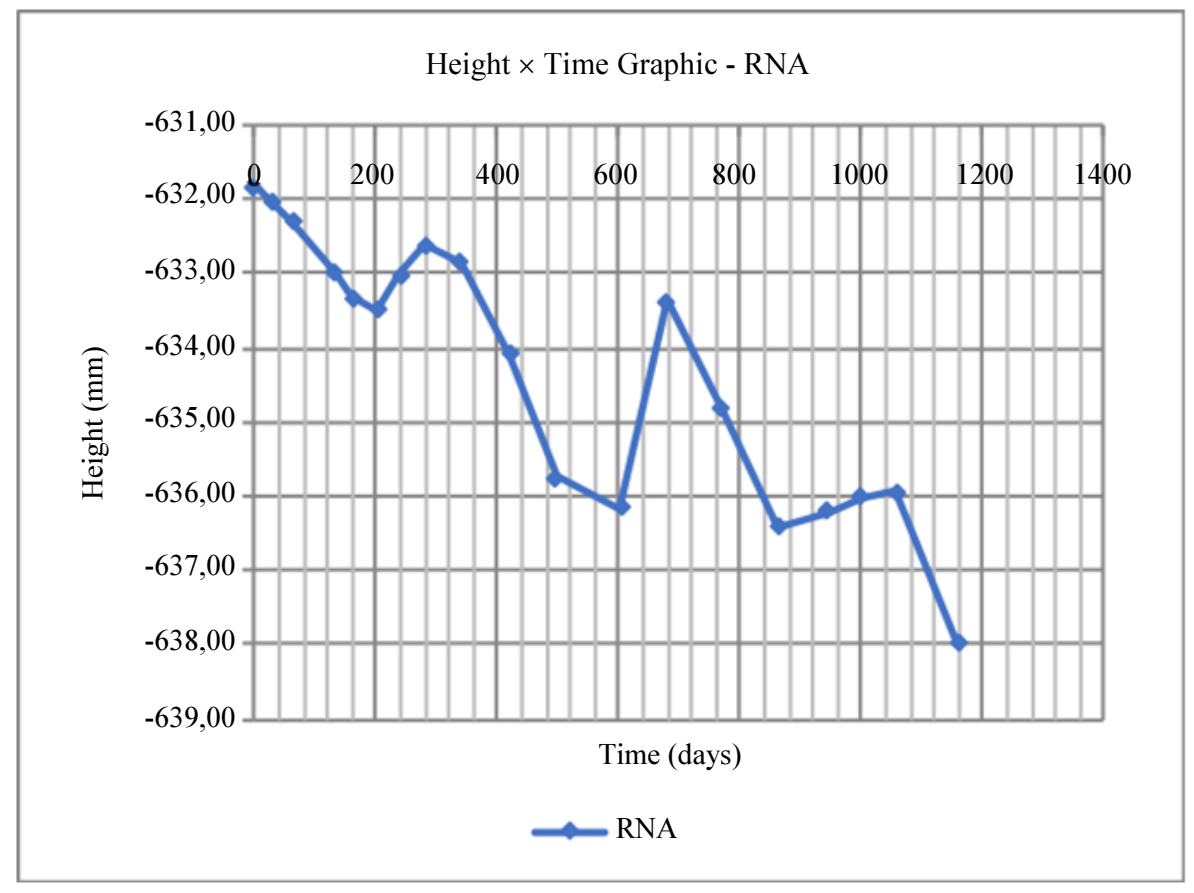

Fig. 9: Height $\times$ Time Graphic from RNA - 19 campaigns of 


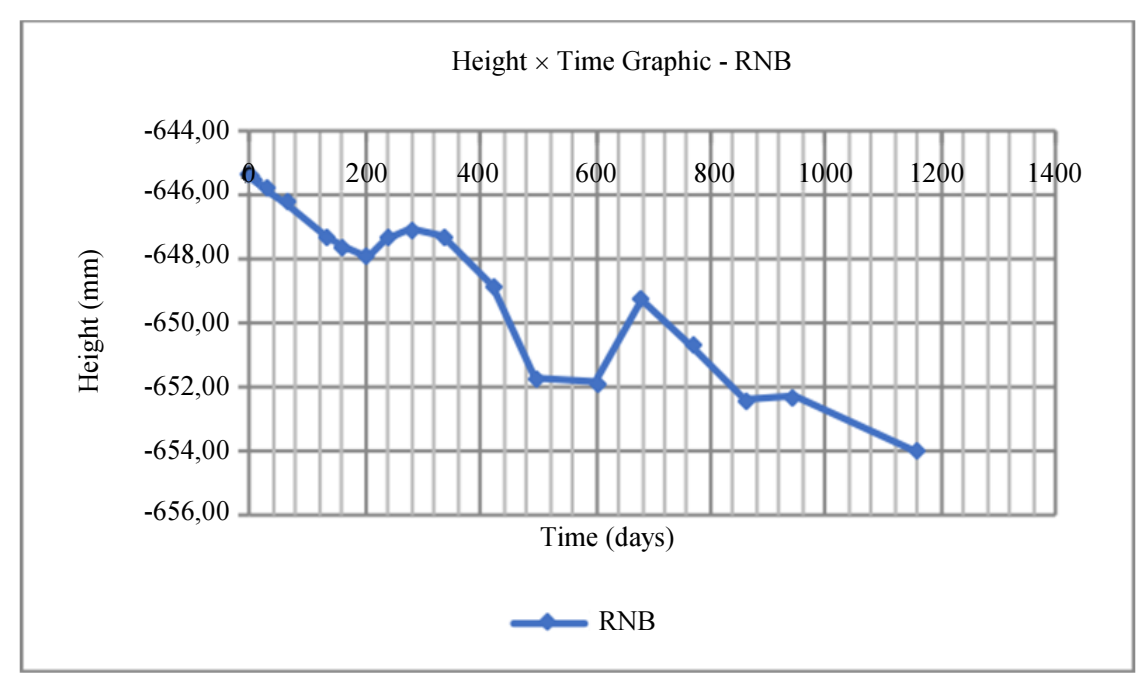

Fig. 10: Height $\times$ Time Graphic from RNB - 17 campaigns of observation

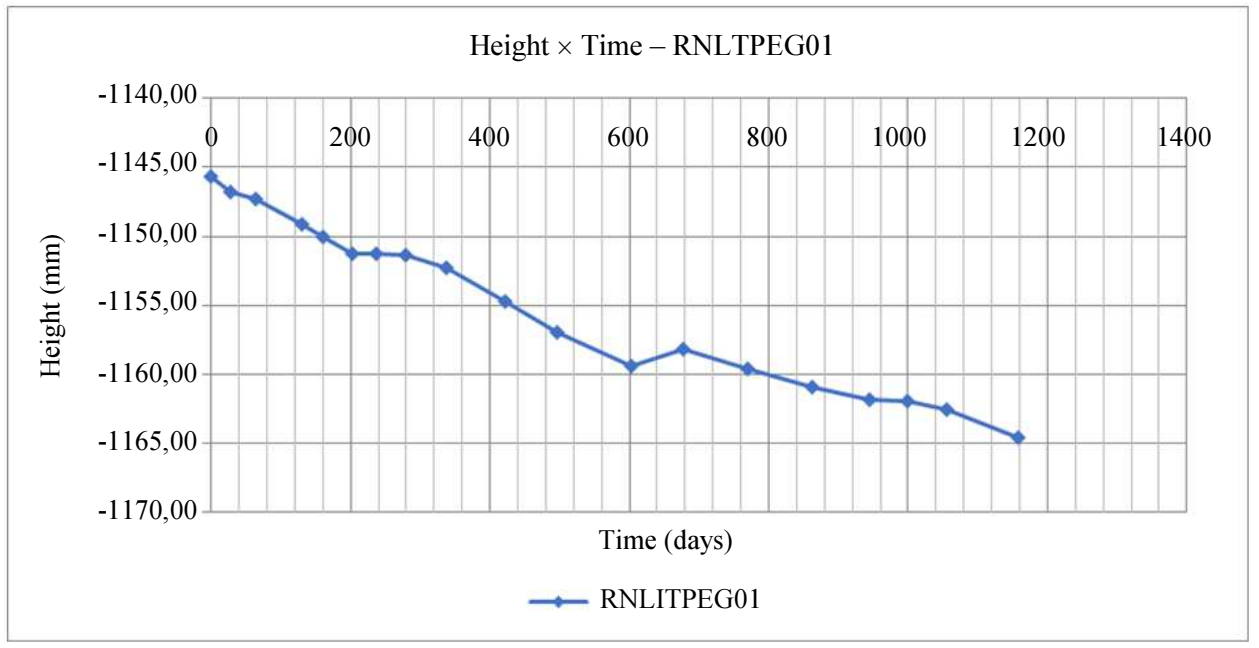

Fig. 11: Height $\times$ Time Graphic from RNLITPEG01 - 19 campaigns of observation

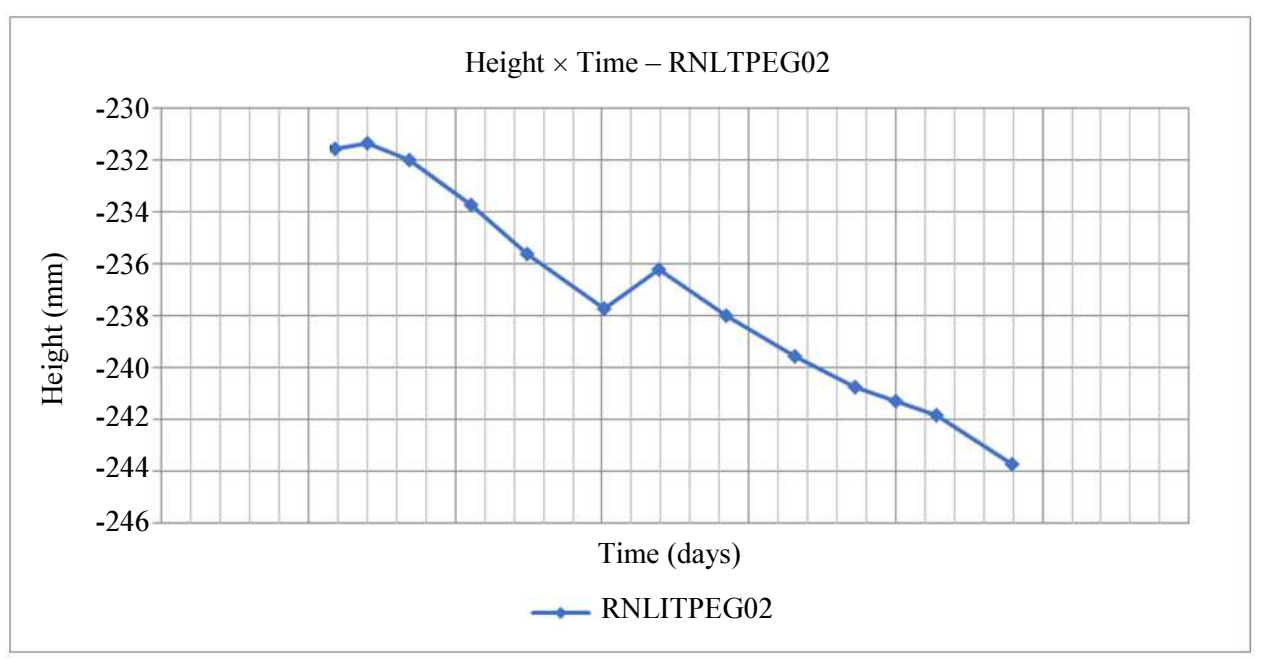

Fig. 12: Height $\times$ Time Graphic from RN LITPEG02 - 13 campaigns of observation 
From the values of the adjusted heights of the RNA, RNB, RN LITPEG01 and RN LITPEG02, the analysis of the mean with the same variance was carried out using the t-student test and the analysis: ANOVA. For the statistical analysis, the determined heights of the level references calculated from the RN CTG01 and grouped per year were considered. Separating for RNA and RN LITPEG01 measurements carried out in 4 samples (sample 1: 3 measurements in 2015, sample 2: 7 measurements in 2016, sample 3: 4 measurements in 2017 and sample 4: 5 measurements in 2018). For RNB, the measurements carried out were separated in 4 samples (sample 1: 3 Measurements in 2015, sample 2: 7 Measurements in 2016, sample 3: 4 Measurements in 2017 and sample 4: 3 Measurements in 2018) and for RN LITPEG02 measurements made were separated in 3 samples (sample 1: 4 Measurements in 2016, sample 2: 4 Measurements in 2017, sample 3: 5 Measurements in 2018). According to the results in Table 8 to 11 , the stability of the level references can be analyzed statistically, according to results presented in Tables 8 to 11 .

Table 8: Summary of the analysis of means with the same variance by t-student test - RNA

\begin{tabular}{llll}
\hline Groups & Estatistic t & t-critical & Conclusion \\
\hline Sample1 $\times$ Sample2 & 3,7866 & 2,306 & Differ \\
Sample1 $\times$ Sample3 & 4,0066 & 2,571 & Differ \\
Sample1 $\times$ Sample4 & 8,6617 & 2,447 & Differ \\
Sample2 $\times$ Sample3 & 3,5703 & 2,262 & Differ \\
Sample2 $\times$ Sample4 & 8,6681 & 2,228 & Differ \\
Sample3 $\times$ Sample4 & 2,1562 & 2,365 & Not differ \\
\hline
\end{tabular}

Fonte: AstGeoTop (2019)

Table 9: Summary of the analysis of means with the same variance by t-student test - RNB

\begin{tabular}{llll}
\hline Groups & Estatistic t & t-critical & Conclusion \\
\hline Sample1 $\times$ Sample2 & 4,6410 & 2,306 & Differ \\
Sample1 $\times$ Sample3 & 6,7924 & 2,571 & Differ \\
Sample1 $\times$ Sample4 & 11,6115 & 2,777 & Differ \\
Sample2 $\times$ Sample3 & 6,0810 & 2,262 & Differ \\
Sample2 $\times$ Sample4 & 10,7677 & 2,306 & Differ \\
Sample3 $\times$ Sample4 & 2,3486 & 2,571 & Not differ \\
\hline
\end{tabular}

Fonte: AstGeoTop (2019)

Table 10: Summary of the analysis of means with the same variance by t-student test-RN LITPEG01

\begin{tabular}{llll}
\hline Groups & Estatistic t & t-critical & Conclusion \\
\hline Sample1 $\times$ Sample2 & 4,4028 & 2,306 & Differ \\
Sample1 $\times$ Sample3 & 14,4412 & 2,571 & Differ \\
Sample1 $\times$ Sample4 & 17,6085 & 2,447 & Differ \\
Sample2 $\times$ Sample3 & 7,0274 & 2,262 & Differ \\
Sample2 $\times$ Sample4 & 11,4949 & 2,228 & Differ \\
Sample3 $\times$ Sample4 & 4,4108 & 2,365 & Differ \\
\hline
\end{tabular}

Fonte: AstGeoTop (2019)
Table 11: Summary of the analysis of means with the same variance by t-student test - RN LITPEG02

\begin{tabular}{llll}
\hline Groups & Estatistic t & t-critical & Conclusion \\
\hline Sample1 $\times$ Sample2 & 6,0319 & 2,447 & Differ \\
Sample1 $\times$ Sample3 & 10,1890 & 2,365 & Differ \\
Sample2 $\times$ Sample3 & 4,9085 & 2,365 & Differ \\
\hline
\end{tabular}

Fonte: AstGeoTop (2019)

Therefore, one can assert from the hypothesis Test, that the null hypothesis (H0: equal population means) and the alternative hypothesis (H1: Different population means), with a level of significance of the test equal to $=$ $5 \%$, that the result of Bi-flow rate: $t \leq t$-critical, performed among all the samples presented in Table 10 (RN LITPEG01) and Table 11 (RN LITPEG02), which the samples mediums are different from the level of $5 \%$ significance. For the same test applied to the RNA and RNB samples, only samples 3 were compared as the samples 4 do not differ, as presented in Table 8 (RNA) and Table 9 (RNB). The ANOVA analysis and the Sheffé test will confirm the results obtained.

The vertical variability of RNA, RNB, RN LITPEG01 and RN LITPEG02, as can be seen in the amplitudes of the measurement series of each observed RN (Table 7) and in the "Height $x$ Time" graphics presented in Fig. 9 to 12 and the results of the statistical tests applied and presented in Tables 8 to 11, confirm that the RNA, RNB, RN LITPEG01 and RN LITPEG02 cannot be used as a fixed vertical reference for the measurement of settlings, but they can be used as an immediate support for the transport of height during each time of observation.

Considering the type of materialization of level references of semi-spherical surfaces (RNA and RNB) of $6 \mathrm{~cm}$ in length and implanted in the sidewalk (base of verification and adjustments of levels (Fig. 3)) and therefore superficial and level references (RN LITPEG01 and RN LITPEG02) of semi-spherical surface fixed with epoxy concrete glue on stems of $2 \mathrm{~m}$ in length and anchored in a concrete base (Fig. 2) in the vicinity of the work, that they can only be used for the height transport at the moment of the measurement of settlements, considering that RNA, RNB, RN LITPEG01 and RN LITPEG02 are superficial level references and they can move vertically over time, according to the time of observation described.

It should be noted that these level references (RNA, RNB, RN LITPEG01 and RN LITPEG02) serve only as an immediate height support for the measurement of the settling pins fixed on the pillars of the monitored buildings.

These experiments reaffirm the need for vertical control of vertical networks used for the monitoring of settlings. 


\section{Definition of the Standard of Height Reference in} the UFPE Campus Recife

Therefore, the Bench Marks RN CTG01 and RN CTG02, according to the results presented and at a significance level of $5 \%$, have vertical stability and thus establish stable height reference standards for the other level references implanted within Campus Recife of UFPE.

These Bench Marks defined a Vertical Local Geodetic Network for the analysis of settlements of LITPEG buildings under construction until the eighteenth campaign held on 11/26/2018, in order to take these height references to the other UFPE Recife Campus Centers.

\section{Conclusion}

To establish a Vertical Local Geodetic Network with metrological reference standards that were implemented within the Campus Recife of UFPE, the height established in the RN CTG01 and RN CTG02 was taken as a vertical reference. The RN CTG01 and RN CTG02 had the purpose of establishing height references for works related to the control and monitoring of settlements of building foundations.

In this context, RN CTG01 and RN CTG02 were investigated. The leveling and counter-leveling measurements are considered, i.e., the leveling lines 11 and 16 shown in Fig. 4, carried out during the campaigns of control measurement and monitoring of settlements, including the vertical local geodetic network composed of the levels reference RN CTG01, RN CTG02, RNA, RNB, RN LITPEG01 and RN LITPEG02, involving a total so far of 19 observation periods (De Seixas and De Seixas, 2019).

For the case investigated and according to the results obtained for the RN CTG02 and having the RN CTG01 as a height reference and presented and analyzed, it can be affirmed at a level of significance of $5 \%$ that RN CTG01 and RN CTG02 are "static". According to Table 1, the adjusted RN CTG02 range varied during a 1159- day interval from $34,56 \mathrm{~mm}$ (L02) to $34,75 \mathrm{~mm}$ (L13), that is, an amplitude of 0,19 $\mathrm{mm}$. In this investigated case the stretch between RN CTG01 and RN CTG02 was leveled and counterbalanced 19 times at different times of the year. Figure 5 illustrates the vertical behavior of RN CTG02 within the observation period and regression analysis shown, with residues in the order of hundredths of millimeters (Table 6), with a slope (m) equal to 0,00004889 and a $\mathrm{y}$-intercept (b) equal to $34,59 \mathrm{~m}$. A statistical analysis of the 19 adjusted heights of the RN CTG02 and distributed in 4 representative samples of the years 2015, 2016, 2017 and 2018, with respect to the analysis of the means with the same variance and from the tstudent test, concluded that the heights at a significance level of $5 \%$ did not differ. The ANOVA analysis also confirmed this result.

Therefore, the level references RN CTG01 and RN CTG02 have vertical stability, at a significance level of $5 \%$ and thus establish stable vertical reference standards for the other level references implanted within the UFPE Campus Recife.

For the measurement of control and monitoring of basements of foundations of buildings under construction within the Campus, a Vertical Local Geodetic Network was set up composed of the RN CTG01, RN CTG02, RNA, RNB, RN LITPEG01 and RN LITPE02. This network was measured up to Reading L18, performed on 11/26/2018, 19 times over a period of 1159 days, taking as a vertical reference the RN CTG01. The observed data were processed and the level reference heights were determined. The graphics shown in Fig. 9 to 12 illustrate the vertical variability of RNA, RNB, RN LITPEG01 and RN LITPEG02. According to Table 7 and the time series of heights of the level references, amplitudes of $6,16 \mathrm{~mm}$, $8,69 \mathrm{~mm}, 19,01 \mathrm{~mm}$ and $12,20 \mathrm{~mm}$ were detected for the RNA, RNB, RN LITPEG01 and RN LITPEG02, respectively. Recalling that RN LITPEG02 was observed from L7 onwards and that the RNB was not measured in the LRP and L17 readings. The heights of the respective level references were analyzed from the statistical analysis of samples with the same variance and ANOVA analysis, noting that they do not meet as stable level references for measurement of settlements, but as an immediate support for height transport to be performed for each observation period.

Therefore, this work reaffirms the need for vertical control of vertical networks used to monitor settlement. This requires at least two points (two vertical references) for the analysis of stability, when a deep level reference is not chosen for economic reasons. It should be noted that the inadequate use of superficial level reference points compromises the reliability of settlement measurements when they are used as stable references without proper vertical control.

The experiments presented in this work and for the case under study prove the use of vertical references fixed in structures of consolidated buildings, that is, built more than 50 years of post-construction and installed on Franki stakes. In this sense, this work presents a solution for defining vertical references with a much lower cost when compared to the solution of references anchored in layers of stable soil with deep rods.

In summary, the methodology for analyzing the stability of level references consists of:

- Define a vertical reference system based on a Vertical Local Geodetic Network with at least two reference points of the same materialization category

- Carry out a time series of observations applying the geometric leveling method with leveling and 
counter-leveling lines or double leveling lines or ring leveling circuits, emphasizing the need to check and adjust the digital level and evaluate its performance

- Assess the quality of the observations

- Determine the unevenness between the points of the reference network and their heights

- Apply analysis of variances (analysis of mean with the same variance and ANOVA) and after finding stability

- Determine the trend line over the time series of heights from the Linear Regression. Excel spreadsheets or specific software, like the ones presented in this work, can be used

\section{Acknowledgement}

To UFPE, to Prof. Dr. Edmilson Santos de Lima and Prof. Dr. Paulo Roberto Maciel Lyra, to the Cartographic Engineering Department for the concession of equipment and accessories rented at the Geodesy LaboratoryLAGEO and to Research Projects $\mathrm{n}^{\circ}$ 23076.040512/2015-15 and $\mathrm{n}^{\circ} 23076.016133 / 2018-57$ PROPESQ/UFPE. We would like to thank Georgia Adriana Williams, Aerospace Engineering Student, for the English revisions.

\section{Funding information}

To Prof. Dr. Edmilson Silva and to the Board of the Center for Technology and Geosciences for the financial resources and scholarships for undergraduate students in cartographic engineering (2016-2017) Research Project $n^{\circ}$ 3076.040512/2015-15 PROPESQ/UFPE and CAPES for the scholarship for pos-graduate student (2015-2017).

\section{Author's Contributions}

The authors participated in all experiments, coordinated the data processing and analysis and contributed to the writing of the manuscript.

\section{Ethics}

This article is original and contains unpublished material. The corresponding author confirms that all of the other authors have read and approved the manuscript and no ethical issues involved.

\section{References}

ABNT, 1996a. Associação Brasileira de Normas Técnicas. NBR 6122/1996: Projeto e execução de fundações. Rio de Janeiro, Brasil.
ABNT, 2010b. Associação Brasileira de Normas Técnicas. NBR 6122/2010: Projeto e execução de fundações. Rio de Janeiro, Brasil.

Blitzkow, D., I.O. Campos and S.R. de Freitas, 2004. Altitude: O que interessa e como equacionar? Proceedings of the 1th Simpósio Brasileiro de Ciências Geodésicas e Tecnologias da Geoinformação, (GTG' 04), Recife-PE, Brasil.

de Freitas, S.R. and D. Blitzkow, 1999. Altitudes e geopotencial. Proceedings of the "IGeS Bulletin N.9 - International Geoid Service, (IGS' 99), Milan, pp: 47-62.

de Seixas, A. and J.R de Seixas, 2015. Controle e Monitoramento de Recalques - Edifício em Construção do Laboratório Integrado de Tecnologia em Petróleo, Gás e Biocombustíveis - LITPEG CTG/UFPE. In: Projeto de Pesquisa $n^{\circ}$ 3076.040512/2015-15 PROPESQ/UFPE.

de Seixas, A. and J.R. de Seixas, 2018. Projeto de Pesquisa: Controle e Monitoramento de Recalques Edifício em Construção do Laboratório Integrado de Tecnologia em Petróleo, Gás e Biocombustíveis LITPEG/CTG/UFPE - Parte 2 Continuação (Medições L11 A L25), processo n 23076.016133/ 2018-57 PROPESQ/UFPE, 2018.

de Seixas, A. and J.R. de Seixas, 2019. Relatório técnico-medição L19-28/03/2019. Controle e Monitoramento de Recalques-Edifício Construído do Laboratório Integrado de Tecnologia em Petróleo, Gás e Biocombustíveis LITPEG/CTG/UFPE.

de Seixas, A., J.R. de Seixas and J.J. de Seixas, 2007. Detecção Geodésica e visualização gráfica da deformabilidade de fundações de edifícios aplicações às estruturas prediais de grande porte vertical. $\mathrm{V}$ Colóquio Brasileiro de Ciências Geodésicas e II Simpósio Brasileiro de Geomática, Presidente Prudente.

de Seixas, A., J.R. de Seixas and J.J. de Seixas, 2008. Measurement, graphics visualization and evaluation of the buildings foundation deformation applications building to high vertical structures. Proceedings of the 13th International Conference on Geometry and Graphics, (CGG' 08), Dresden.

de Seixas, A., J.R. de Seixas and J.J. de Seixas, 2009. Auscultação geodésica no controle de recalque da fundação de edifício predial de grande porte. Boletim de Ciências Geodésicas.

de Seixas, A., J.R. de Seixas and J.J. de Seixas, 2012. Verification and control of vertical bench mark applied for settling measurements of large structure buildings. Proceedings of the FIG Working Week Knowing to Manage the Territory, Protect the Environment, Evaluate the Cultural Heritage, May 6-10, Rome, Italy. 
de Seixas, A., J.R.de Seixas and R.P.C. Seixas, 2019. Analysis of the altimetric stability of the standard level references implanted in the campus-UFPE for the study of settlings. Proceedings of the 27th IUGG General Assembly, (IGA’ 19), Montreal.

de Seixas, A., J.R.de. Seixas and J.J.de. Seixas, 2006. Control and monitoring of buildings foundation application in very high buildings structures. Proceedings of the 23 International FIG Congress, (IFG' 06), Munique.

de Seixas, A., L.F. Gama, J.N. Moraes and A.M.B. Souza, 2014. Estabelecimento de padrões de referência altimétrica utilizando o nivelamento geométrico para a definição de alvos altos e inacessíveis. Boletim de ciência geodésica, Curitiba, 20: 388-410.

Garnés, S.J.A., 2019. AstGeoTop. Software. Recife-PE: Departamento de Engenharia Cartográfica. Universidade Federal de Pernambuco, Brasil.

Gemael, C., 1994. Introdução ao Ajustamento de Observações: Aplicações Geodésicas. 1st Edn., ISBN-10: 8585132922, pp: 319.

Ingensand, H., 1990. Das wild NA 2000. Das erste digitale Nivellier der Welt. Allgemeine Vermessungs Nachrichten, 97: 201-210.

Ingensand, H., 2002. Check of digital levels. Proceedings of the FIG 22th International Congress on TS5.11 Standards, Quality Assurance and Calibration, Apr. 19-26, Washington, D.C. USA.

ISO, 2001. International Organization for Standardization. ISO 17123-2/2001: Optics and optical instruments-Fiel procedures for testing geodetic and surveying instruments - Part 2: Levels.

Kahmen, H., 2006. Angewandete geodesie: Vermessungskunde. De Gruyter.

Moeser, M., H. Hoffmeister, G. Mueller, R. Staiger and H. Schlemmer et al., 2012. Handbuch Ingenieurgeodasie, Grundlagen. 1st Edn., Wichmann Publishing House, ISBN-13: 978-3-87907-504-1, pp: 628.

Niemeier, W., 2002. Ausgleichungsrechnung, de gruyter. Santos, W.J., A. de Seixas and S.M. Santos, 2019. Evaluation of the application and efficacy of geodetic and topographic methods in inclined land surveys susceptible to risk areas. Revista Anuário do Instituto de Geociências - UFRJ, 42: 267-283.

Schwarz, W., 2002. Geodaetische messverfahren fuer das bauwesen. DVWe.V.-Geselschaft fuer Geodaesie, Geoinformation und Landsmanagement. Schriftreihe 43/2002-Interdisziplinaere Messaufgaben im Bauwesen. Wittwer.
Silva, E.V. and A. de Seixas, 2017b. O estabelecimento de padrões de referência Metrológica: Controle e análise da qualidade de Estruturas geodésicas altimétricas implantadas no Campus recife da UFPE. Revista brasileira de Cartografia (2017), $\mathrm{N}^{\circ}$ 69/9, Edição Especial Geotecnologias e Desastres Naturais: 1807-1832 Sociedade Brasileira de Cartografia, Geodésia, Fotogrametria e Sensoriamento Remoto, ISSN: 1808-0936, p.1807 a 1832.

Silva, E.V. and A. de Seixas, 2019. Analysis of the stability of the local altimetric geodetic network densified on the campus recife UFPE. Revista Anuário do Instituto de Geociências - UFRJ, 42: 350-365.

Silva, E.V., 2017. Monitoramento de estruturas geodésicas altimétricas e estabelecimento de padrões de referência metrológica: Campus recife da UFPE. Published master dissertation for the degree of Master of Science, Federal University of Pernambuco, Recife, Brazil.

Silva, E.V., A. de Seixas, 2017a. Análise temporal da qualidade de estruturas da RAAP no campus recife da UFPE e o estabelecimento de uma rede altimétrica local. Proceedings of the 4th Simpósio Brasileiro de Geomática and 2th Jornadas Lusófonas-Ciências e Tecnologias de Informação Geográfica, (TIG' 17), Presidente Prudente, Artigo Completo, Presidente Prudente, UNESP, pp: 423-429.

Silva, E.V., W.J. Santos, P.H.O.N. Pestana and A. de Seixas, 2018. Metodologia para verificação e classificação de nível digital conforme a ISO 171232. Proceedings of the 7th Simpósio Brasileiro de Ciências Geodésicas e Tecnologias da Geoinformação, Nov. 08-09, Recife-PE.

Silva, I. and P.C.L. Segantine, 2015. Topografia para engenharia: Teoria e Prática de Geomática. Rio de Elsevier, Janeiro.

Torge, W., 2001. Geodesie. 2nd Edn., Gruyter Lehrbuch, Berlin.

Wolf, P.R. and C.D. Ghilani, 1996. Adjustment Computations: Statistics and Least Squares in Surveying and GIS. 3th Edn., John Wiley and Sons Inc., New York. 